\title{
Collective space of high-rise housing complex
}

\author{
Tatyana Bakaeva ${ }^{1, *}$ \\ ${ }^{1}$ Samara State Technical University, Molodogvardeyskaya St, 194, Samara, Russia
}

\begin{abstract}
The article considers the problems of support of citizens a comfortable living environment in the conditions of the limited territory of the megalopolis, the typological principles of formation of space-planning structure high-rise residence complexes with public space. The collective space for residents of high-rise housing estates on the example of international experience of design and construction is in detail considered. The collective space and the area of the standard apartment are analysed on comfort classes: a social - complex Pinnacle@ Duxton, a business Monde Condos and an elite - Hamilton Scotts. Interdependence the area of the standard flat and the total area of housing collective space, in addiction on the comfort level, is revealed. In the conditions of high-density urban development, the collective space allows to form the comfortable environment for accommodation. The recommendations for achievement of integrity and improvement of quality of the city environment are made. The convenient collective space makes a contribution to civil policy, it creates the socializing sense of interaction of residents, coagulates social effect.
\end{abstract}

\section{Introduction}

Relevance of a research is caused by need of improvement of consumer qualities of the inhabited environment. Carrying out in-depth studies in the field of typology of the dwelling and on formation of structural elements of the inhabited environment depending on economic characteristics and requirements of various social groups becomes the most important. Now there was a certain stereotype of perception of comfortableness of housing depending on its area. This article demonstrates other spatial and environmental ideas of the qualitative inhabited environment in the conditions of megalopolis hyper density. Problem of this research is to analyse international experience of design and construction. The purpose of the current research to prove that comfort of the apartment isn't in direct dependence on its area.

The research is based on theoretical works of such authoritative researchers of the dwelling as Generalov V. P., Generalova E. M., Potiyenko N. D., Grigoriev I. V., Durmanov V. Yu., Kartashova K. K., Kaydalova E. V., Kiyanenko K. V., Krasheninnikov A. V., Molchanov V. M., Ovsyannikov V. A., Yargina Z. N. and others.

\footnotetext{
*Corresponding author: 881019@mail.ru
} 
According to the aim it is necessary to solve research problems. Not always it is possible to call housing, big on the area, comfortable and, on the contrary, the apartment very modest can meet all requirements imposed to the modern dwelling by means of set of services and the services, provided by a housing estate, which part it is for metric area [1-4].

For detailed consideration of international experience of construction of high-rise housing we will concentrate on such indicators as the area of the standard flat and the total area of housing collective space.

We will consider the dwelling as set of manifestations of activity of the person, various on degree of a privacy, in the course of accommodation. As a part of an inhabited cell it is possible to allocate, directly, residential zone where private individual needs are carried out, there are also communicative needs of the person to self-realization through socialization and interaction with society [5-10].

\section{Methods}

The research leans on the following methods: 1. Studying and the analysis of references, results of scientific developments and design decisions on the chosen subject; 2 . Consideration of international experience of design and construction of inhabited houses complexes of the increased number of stories with multilevel public space.

\subsection{Collective space in a social high-rise housing complex}

Striking example of comfortable housing with the developed collective space as a part of a housing estate in the conditions of hyper dense building of the megalopolis is Pinnacle @ Duxton (fig. 1a). This complex is an award-winning 50-storey residential development in Singapore's city center, next to the business district. All seven connected towers are collectively the world's tallest public residential buildings. Unique amongst Housing and Development Board (HDB) projects, it is the design winner of a worldwide competition [11]. The Pinnacle @ strikes Duxton designed by ARC Studio Architecture + Urbanism with altitude (163 m for Asian skyscrapers - very average height) and scale (1848 apartments on the area of 2,5 hectares, the total area of a complex about $280000 \mathrm{~m}^{2}$. The characteristic of this HDB precinct is that as of now, it is one of the highest public housing precinct in Singapore. The building offers the unique concept of mass housing for the densely populated cities. It is the courageous experiment in the field of typology of high-rise housing resolving functional, economic and social issues, confirming in practice that high-rise building can form the comfortable inhabited environment [1]. The Pinnacle@Duxton is sated with all necessary public functions: shopping centers, enterprises of food, educational center, kindergarten, sports both playgrounds and etc. In addition are in the radius of pedestrian availability: police, hospital, restaurants, bars, cafe, shops, etc. It is competently organized traffic and pedestrians, level for the movement of fire trucks, and also special transport for garbage removal is provided. The bend of towers forms extensive domestic space, keeping communication with the existing public center of regional value "Tanjong Pagar". In the territory of the yard are provided: children's playgrounds, a set of zones of quiet rest with gardening, the covered arbors and benches, the universal sports ground, and also historical park. The yard represents the raznourovnevy space united by system of ramps that makes him easily available for handicapped groups of the population (fig. 1b).

The project features the world's two longest sky gardens of 500 meters $(1,600 \mathrm{ft})$ each, on both the 26th and 50th floors. Uniting seven high-rise blocks, these platforms form a laconic sculptural silhouette of a complex, being his business card. They not only expand 
public space, but also perform function of a comfortable recreation area for residents and visitors of the building. Heavenly galleries give in addition to the land level 1 more hectare of the well-planned territory. It offers three levels of public spaces whereby of $50 \%$ of the site on the ground is public while the 26th floor and 50th floor sky bridges account each for 21 of $\%$ of the total site. On them the survey platforms, jogging track and zones created by various thematic landscape compositions are organized. In total There are 12 heavenly gardens of All exists 12 sky gardens. There are sky gum, meadows, space net, crater, padi field, observation deck on the 26th floor. There are cottage, rocky, beach, lounge, hillock, fiesta on the 50th floor. At the same time these collective spaces of sky bridge perform function of zones for evacuation during the fire, and also facilitate engineering service of a facade. A variety of apartments is presented by 35 different version of planning of inhabited cells. Also a possibility of re-planning exists, because internal partitions are made of lightweight concrete. Smaller flats measuring 93 to $97 \mathrm{~m}^{2}$ and bigger ones measuring 105 to $108 \mathrm{~m}^{2}[12]$.

All public space of the precincts is located at ground level, raised platform level and skybridges. Total multilevel provision of public space: Ground open area incl. pavillions $9600 \mathrm{~m}^{2}$, Elevated open area $24000 \mathrm{~m}^{2}$, Ground level void deck $4000 \mathrm{~m}^{2}$, Upper level void deck $4000 \mathrm{~m}^{2}$ [13].

To understand the opportunities of access to public space as a part of a housing complex, necessary enter the coefficient of saturation collective space.

$$
K_{S C S}=S_{T F} / S_{C S}
$$

The coefficient of saturation collective space $\left(K_{S C S}\right)$ is equal to the relation of the area of the typical flat $\left(S_{T F}\right)$ to the total area of housing collective space $\left(\boldsymbol{S}_{C S}\right)$.

Calculation for the complex Pinnacle@Duxton:

$$
\boldsymbol{K}_{\text {scs }}=100.5 \mathrm{~m}^{2} / 41600 \mathrm{~m}^{2}=0.0024
$$

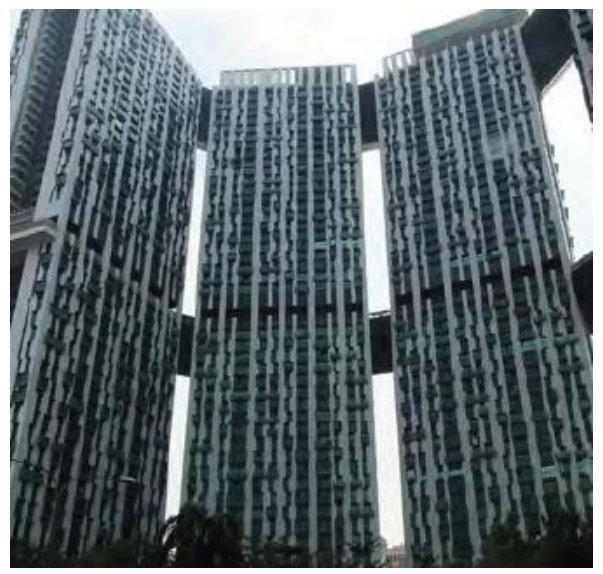

a

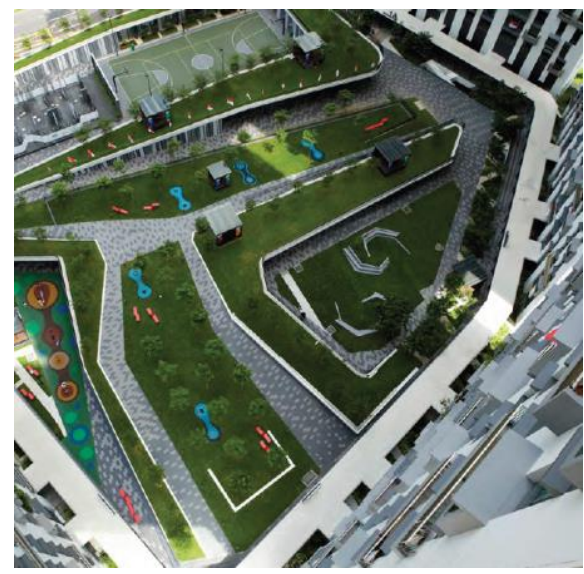

b

Fig. 1. Pinnacle@Duxton: a - look outside, b - the collective space of platform

\subsection{Collective space in a high-rise housing complex of a business class}

Monde Condos (fig. 2a) is a dramatic 40-storey building of a business-class at Queen's Quay and Bonnycastle, Toronto. The main entrances to both the tower and the podium are off of Bonnycastle Street. The architecture of Monde, a groundbreaking building targeting 
LEEd Gold certification comes from internationally recognized architect Moshe Safdie in collaboration with Quadrangle Architects. These masters of design worked with Cecconi Simone on the interiors and Janet Rosenberg \& Studio on the landscape design to create a building with premium quality standards a design aesthetic inspired by nature, the lake and the city. Monde features a breathtaking double-height lobby with a living green wall, along with extensive amenities designed by acclaimed interior design firm Cecconi Simone. The collective space (fig. 2b) will be located on the entire tenth floor and will include yoga/pilates/cardio/kinesis training and weights studios, hot plunge pool and his and hers sauna, steam and change-rooms with experience showers. Relax and entertain in the kitchen/dining/bar/lounge and play in the billiards room. Outside enjoy the outdoor lounge with indoor/outdoor fireplace or relax in a cabana deck side next to the outdoor pool with infinity views to Lake Ontario. Extensive landscaping by celebrated Janet Rosenberg \& Studio complements the pool deck.

There are many amenities: 24 hour and 7 day a week concierge, 2 guest suites provided for residents' use, resident superintendent for on-site maintenance, underground parking equipped with security monitoring system, underground garage painted white and well-lit for added safety and security, 5 custom-designed elevators - 3 designated for the tower and 2 for the podium, vistor parking on the uppermost parking level, separate lobby access for podium and tower with mailrooms conveniently located beside each.

Monde is a member of the "Intelligent Community" at Waterfront Toronto, an open-access network that provides internet speeds of up to 100 times faster than anywhere in the city.

Total number of suites is 516 , suite size range $45-92 \mathrm{~m}^{2}$. The total are of architects is 3200 $\mathrm{m}^{2}[14-19]$

Calculation for the complex Monde Condos by means formula (1):

$$
\boldsymbol{K}_{\text {scs }}=68 \mathrm{~m}^{2} / 3200 \mathrm{~m}^{2}=0.021
$$

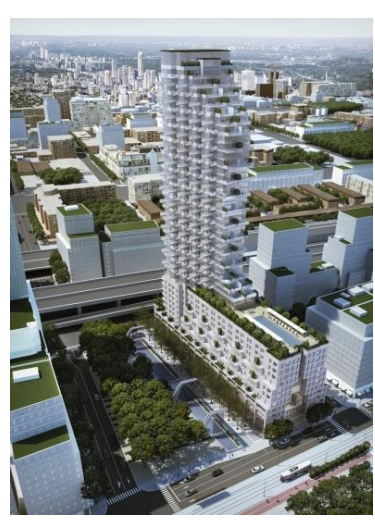

a

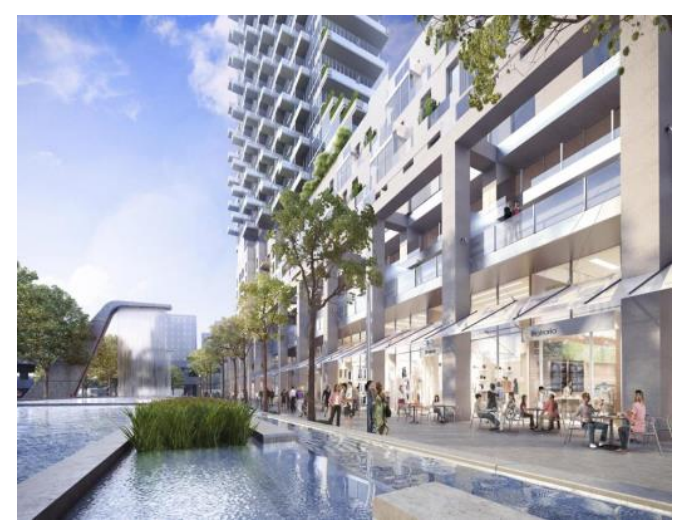

$\mathrm{b}$

Fig. 2. Monde Condos: a - look outside, $\mathrm{b}$ - the collective space of Monde Condos

\subsection{Collective space in an elite high-rise housing estate}

Hamilton Scotts (fig. 3a), a high-class apartment condominium in Singapore, one of the most innovative residences in the country and perhaps the whole of Asia, is offering its residents the ultimate luxury in terms of parking - an individual two-car garage located inside each apartment. A glass wall separates the garage from the living room, offering a lovely view of their expensive cars from the couch. 
The system is quite simple - when residents enter the building, they need to park their cars inside a glass elevator shaft. The elevator then raises the vehicle up to the corresponding condo and parks it within a glass enclosure that is visible from the living room. Although the Hamilton Scotts condo numbers 30 floors and tens of thousands of square meters of living space, there just wasn't enough to build a multi-level parking for the residents. Faced with this challenge, the team of architects and engineers in charge of development came up with something so much better. The unique design enables supercar owners to showcase their prized possessions, instead of hiding them away in basement garages. Hamilton Scotts is the world's first building to offer such an advanced system of parking [20]. This single block residential property offers a full range of facilities to future residents along with an impressive array of outside amenities for people who want to live it up and enjoy the fruits of their labors. There are many facilities such as a gym, conference rooms, jacuzzis, 24 hours security, a barbeque corner and a residents' lounge, Meeting Rooms, Swimming Pool (fig. 3b) [21, 22].

On floors from the 2nd for the 27th 54 apartments with three bedrooms (on two apartments on the floor) of $256 \mathrm{~m}^{2}$ are located. Two penthouses finish a tower, with a one area of $300 \mathrm{~m}^{2}$ occupies the 28th floor, other more magnificent of $661 \mathrm{~m}^{2}$ - two-level, it was located on the 29th and 30th floors. In penthouses at the disposal of owners on four parking spaces. All bedrooms have personal bathing and wardrobe [1, 3]. Apartments are characterized spacious layout with luxury finishing, private lift and modern interiors with 3 en-suites designed with meticulous attention. There are fully equipped kitchen and premium fittings, large spacious balcony with unobstructed greenery and city views. Each unit will have 3 parking lots. (2 lots at Sky Garage +1 Basement lot) [23-27]. The additional entrance to the apartment is carried out from the public ladder and lift knot, performing function of an emergency and economic exit. The total area of housing collective space is $1540 \mathrm{~m}^{2}$.

Calculation for the complex Hamilton Scotts by means of formula (1):

$$
\boldsymbol{K}_{\text {scs }}=256 \mathrm{~m}^{2} / 1540 \mathrm{~m}^{2}=0.16
$$

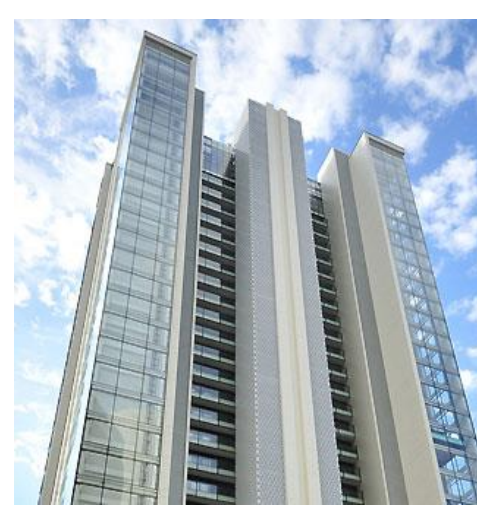

a

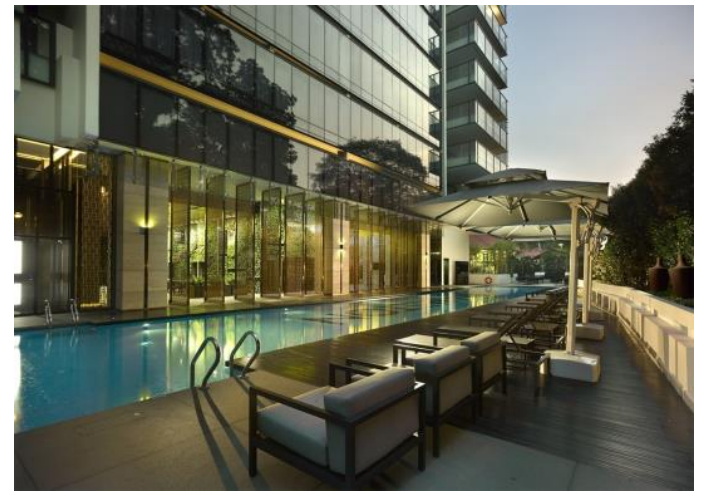

b

Fig. 3. Hamilton Scotts: a - look outside, b - the collective space of Hamilton Scotts

\section{Results}

The coefficient of saturation collective space $\left(\boldsymbol{K}_{S C S}\right)$ is equal respectively: in the social class 0.0024 , in the business-class 0.021 and in an elite-class 0.16 . 


\subsection{The saturation collective space in the social high-rise housing complex}

Take into consideration the calculations for the complex Pinnacle@Duxton by means of formula (1). Thus, a ratio of the considered categories of the areas:

$$
S_{T F}: S_{C S}=41600 \mathrm{~m}^{2}: 100.5 \mathrm{~m}^{2}=1: 411
$$

Calculations show that, having in property, or, being a tenant of one conventional unit of the private area, the resident can take the benefits and advantages of the collective area equal to 411 conventional units.

\subsection{The saturation collective space in the high-rise housing complex of a business -class}

In view of the calculations for the complex Monde Condos by means of formula (1). Thus, a ratio of the considered categories of the areas:

$$
S_{T F}: S_{C S}=3200 m^{2}: 68 m^{2}=1: 47
$$

Calculations show that, having in property, or, being a tenant of one conventional unit of the private area, the resident can take the benefits and advantages of the collective area equal to 47 conventional units.

\subsection{The saturation collective space in an elite high-rise housing estate}

Take into consideration the calculations for the complex Hamilton Scotts by means of formula (1). Thus, a ratio of the considered categories of the areas:

$$
S_{T F}: S_{C S}=1540 m^{2}: 256 m^{2}=1: 6
$$

Calculations show that, having in property, or, being a tenant of one conventional unit of the private area, the resident can take the benefits and advantages of the collective area equal to 6 conventional units.

\section{Discussion}

In the social high-rise housing complex the public places, that used complex residents are opposite to inhabited cells concernly the square at the person. The most part of all public area of the complex using how a zone of storage of bicycles and reception of guests, gym, a laundry, green terrace on a roof, trade, offices. It is supposed, for example, that residents will receive guests in special guest game rooms, access to which is provided according to the preliminary application.

In the high-rise housing complex of a business class the collective space, available only to residents of a complex, is less contrast on the metric area of standard apartment, however, rather brightly expressed in composition of inhabited structure.

Elite housing assumes, as a rule, the communicative spaces for the inhabitants developed on the areas. However distinctive feature is comparative small functional variability of such zones. In view of extremely wide quantity of the opportunities which are maked directly inside private apartments. The most various functions in this segment of the 
real estate are drawn, generally, towards individual manifestation, emphasizing, thereby, exclusiveness, uniqueness and privileges of the owner.

Future researches have to develop the idea of interdependence the area of the standard flat and the total area of housing collective space. Study in the long term must show, in addiction on the comfort level, the position of development high-rise living collective space changes.

\section{Conclusions}

Depending on the level of comfort of the dwelling, the ratio of living space to the total area of the apartment, changes. So in the social class an inhabited part occupies $80 \%$ of the general space, and in elite - only $30 \%$ of total area, i.e. with increase in the area appears many additional rooms allowing to carry out various functions. But apartments the social and comfort - classes can be not less representative because some functions, except for private, can be carried out by residents directly in the territory of a living complex.

It should be noted that functional zoning and degree of a saturation of services of the serving structure and private space also variously depending on the level of comfort of a housing complex. At the same time the serving infrastructure is subdivided into the public space focused on the city, and on the collective space intended only for building residents. The qualitative collective space makes a contribution to civil policy, it makes the socializing sense of interaction of residents, coagulates social effect the fact of the existence in architectural planning solution of the high-rise housing complex.

\section{References}

1. V. P. Generalov, High-rise residential buildings and complexes. Singapore. Experience of design and construction of high-rise housing (Samara, Ltd Kniga, 2013)

2. V. P. Generalov, E. M. Generalova, High-rise residential complex houses as the element of creating highly comfortable living environment, SGASU vestnik, 2, 12-16 (2013)

3. V. P. Generalov, Architectural design of an apartment house of section type, V.P. Generalov, E. M. Generalova, 17, 164 (Samara, Ltd Kniga, 2013)

4. I. A. Bondarenko, Architecture of the changing Russia: state and prospects Russian academy architectural and construction sciences, scientific research institute of the theory and history architecture and town planning, 464 (Moscow, Komkniga, 2011)

5. V. A. Nefyodov, Landscaping and stability of the environment, (St.-Petersburg, 2002)

6. V. A. Nefyodov, City Landscaping (St.-Petersburg, 2012)

7. Design of modern high-rise buildings, ACB, 330 (2012)

8. A. A. Magaj, Features of architectural typology of high-rise buildings, Architecture and construction of Russia, 4, 22-29 (2009)

9. I. Chizhov, Skyscrapers and people, Architecture and construction, 1, 36-42 (2009)

10. M. F. Utkin, Architectural design of the inhabited environment (Moscow, ArchitectureC, 2010)

11. https://en.wikipedia.org/wiki/The_Pinnacle@Duxton (last accessed 04/15/2017)

12. http://eresources.nlb.gov.sg/infopedia/articles/SIP_1779_2011-02-18.html accessed 04/19/2017) 
13. http://wohnforum.arch.ethz.ch/sites/default/files/dateien/fcl_booklet_final_0915_light. pdf (last accessed 04/10/2017)

14. http://urbantoronto.ca/database/projects/monde (last accessed 04/10/2017)

15. https://condonow.com/Monde-Condos (last accessed 04/11/2017)

16. http://www.pacecondo.ca/monde (last accessed 04/11/2017)

17. https://www.condosky.com/condo/monde-condos/ ( last accessed 04/11/2017)

18. http://www.blogto.com/city/2012/11/new_in_toronto_real_estate_monde_condominiu $\mathrm{ms} /$ ( last accessed 04/12/2017)

19. http://www.listofcondo.com/Monde_Condos/page_2443300.html (last accessed 04/12/2017)

20. http://www.odditycentral.com/architecture/luxury-singapore-skyscraper-allowsresidents-to-park-their-cars-in-the-balcony.html (last accessed 04/14/2017)

21. http://www.designboom.com/architecture/hamilton-scotts-singapore-reignwood-towersky-garages-12-03-2014/ (last accessed 04/14/2017)

22. https://www.propertyreview.sg/hamilton-scotts/ (last accessed 04/17/2017)

23. https://vincentongvirtualhomes.com/hamilton-scotts-scotts-road/\#Project Details (last accessed 04/17/2017)

24. https://en.wikipedia.org/wiki/Tower_block (last accessed 04/20/2017)

25. http://global.ctbuh.org/resources/papers/download/294-humanizing-high-riseurbanism-design-strategies-and-planning-tools.pdf (last accessed 04/20/2017)

26. http://www.kopproperties.com/developments/hamilton-scotts (last accessed 04/20/2017)

27. http://www.stproperty.sg/condominium-directory/reignwood-hamilton-scottscondo/11811(last accessed 04/20/2017) 